\title{
KEMAMPUAN MEMORI KHATIB DALAM MENGINGAT MATERI KHOTBAH
}

\author{
Oleh : Rizal H Arsyad
}

\begin{abstract}
Abstrak
Tugas intelektual lain yang dialami semua orang dalam menghadapi dunia adalah mengingat berbagai hal. Kita mengalami susahnya berusaha menghafal untuk ujian dan mengalami kesulitan Saat berusaha mengingatingat daftar tanggal atau nama atau berbagai informasi dan aktavitas lainnya. bila memungkinkan kita akan menggunakan alat hantu seperti daftar belanjaan, kalender, ringkasan catatan kecil yang memuat katakata kunci, untuk membantu kita mengingat hal-hal yang kita tahu berdasarkan pengalaman yang biasanya kita lupakan.
\end{abstract}

Seorang khotib pun dalam menyampaikan khotbah tentu tidak lepas dari kesusahan menghafal dan kesulitan dalam mencamkan kesan. Mencamkan dapat terlaksana secara tidak sengaja apabila kesan yang didapat tidak dengan disertai perhatian. Sedangkan, mencamkan dengan sengaja dilaksanakan dengan penuh perhatian, aktif dan bertujuan.

Menyimpan adalah apa yang telah dipelqiari atau apa yang telah dimasukkan dapat ditimbulkan kembali apa bila dibutuhkan. Memproduksi adalah suatu keaktifan jiwa untuk membangun kembali kesan-kesan yang telah diterimanya.

Kata Kunci:

Mencamkan, menyinpan, memproduksi, materi khotib 


\section{Pendahuluan}

Dalam konteks kehidupan modern indusatrial, gerakan dakwah Islam dituntut untuk mampu mengaktualisasikan peran Al Qur'an surah Ali Imran (110), yakni sebagai proses humanisasi dan emansipasi. Konsep-konsep normatif dari pesan Islam diterjemahkan menjadi teori-teori sosial yang profetik kemudian melahirkan praksis sehingga Islam menjadi objektif dalam realitas kehidupan, baik dalam kehidupan para pemeluknya, maupun menjadi rahmat bagi semesta alam. Peran dakwah yang demikian yang menjadi tuntutan dan tugas luhur para da'i atau mubaligh demikian halnya dengan para khotib.

Khotbah jum'at merupakan salah satu media dakwah yang cukup efektif di bandingkan dengan media dakwah hil lisan lainnya. Khotbah jumat cukup cfektif karena disampaikan pada tempat, waktu, dan jamaah yang sudah tetap. Selain itu, khotbah jum'at memiliki enam rukun khotbah yang harus dipenuhi dan dilaksanakan pada saat khotbah berlangsung.

Dengan karakter khotbah .iumat seperti itu, menuntut para khotib untuk memiliki kemampuan yang cukup dalam melaksanakan tugas sebagai khotib, baik dari segi pcmahaman agama, ilmu pengetahuan umum, integritas moral yang baik, memahami dan memiliki informasi objek dakwah atau jamaah, serta kemampuan retorika yang cukup, juga tak kalah penting adalah penguasaan materi khotbah.

Bila khotib dengan kriteria kemampuan dan keterampilan seperti disebutkan di atas pada gilirannya diharapkan mampu mengkomunikasikan materi khotbah secara baik, lancar, sistematis, mudah dipahami, fasih dalam pengucapan ayat maupun hadis sehingga audiens dapat dan dengan mudah menerima ajakan dan uraian khotbah yang disampaikan.

Sebaliknya bila khotib tidak memiliki kemampuan dan ketrampilan yang cukup dalam mengkomunikasikan khotbahnya maka berakibat terhadap pesan agama yang dikhotbahkan kurang mendapat perhatian, materi tidak akan menimbulkan kesan pada jamaah dalam merubah pikiran dan motivasi beramal dalam kehidupannya.

Sejalan dengan permasalah mubaligh atau khotib yang disinyalir oleh Haedar Nashir bahwa "khusus dalam khotbah jumat, masih kuat kecenderungan sementara khotib yang indoktrinatif (dengan kekayaan pesan yang terbatas), sajian yang bertele-tele dan panjang dan lebih menggugah iman dan religiusitas, sehingga dirasa kurang tepat di saat suasana jumat 
yang seringkali bagi jamaah harus berjuang ganda dalam mencema materi khutbah yang kurang menarik dan sekaligus melawan kantuk di siang hari. ${ }^{1}$

Di sinilah peran khotib dituntut untuk menyampaikan risalah agama, walau dalam kondisi jamaah yang harus menahan kantuk di siang hari namun bila penampilan khotib yang mampu menggugah para audiens (jamaah) jumat, maka khotib yang sudah profesional dan sering menyampaikan khotbah, akan semakin menarik dan menggugah, ia mudah mengingat dan merangkai kata yang singkat, padat dan sistematis, begitu pula melafalkan ayat maupun hadis secara fasih karena sudah sering diulas atau diceramahkan

Tulisan ini sangat menarik, karena penulis membahas tentang khotib dan kaitannya dengan kemampuan memorinya dalam mengingat materi khotbah; dimana penulis mengadakan pengamatan terhadap setiap khotib yang menyampaikan khotbahnya di masjid.

Tulisan ini membahas tentang kemampuan memori khotib dalam mengingat materi khotbah. Untuk mencapai tingkat keberhasilan kemampuan memori seorang khotib dalam mengingat materi khotbah dalam praktek atau penerapannya masih mengalami masalahmasalah sebaga berikut: 1) Kemampuan memori khotib yang belum terasah dengan baik akan mengakibatkan penyampaian khotbah yang miskin materi, 2) monoton dan tidak fasih dalam melafadzkan ayat Al-Qur'an maupun hadis.

\section{Kajian Teori}

\section{Struktur Otak dan Memori}

Otak sebagai salah satu alat tubuh yang sangat berpengaruh, karena merupakan pusat komputer dari dari semua alat tubuh, bagian dari syaraf yang terletak di dalam rongga tengkorak yang dibungkus oleh selaput Otak yang kuat. ${ }^{2}$ Otaklah yang menetukan makhluk hidup bergerak, memerintahkan indera, menuntut dan mengadakan persepsi, mmengatur pola komunikasi, menentukan jumiah informasi dan sekaligus menyeleksinya.

${ }^{1}$ Pustaka Suara Muhammadiyah, Tuniunan Tabligh, Jilid I (Yogyakarta: Mitra Graflka, 1997), h. 243.

${ }^{2}$ Abdul Rahman Shaleh dan Muhblb Abdul Wahab, Psikilogi Suatu Pengantar Dalam Perspektif Islam (Jakarta: Pemada Media, 2004), h. 63. 
Otak mcrupakan salah satu unsur dari sistem syaraf. Sistem syaraf pada manusia adalah sebuah mesin yang rumit. Sistem ini terdiri dari jutaan sel syaraf yang diperkirakan 12 sampai 200 juta sel. Otak inilah yang menggerakkan dan mengkoordinasi kerja selsel tersebut sedemikian rupa sehingga mampu mendengar, berpikir, mengingat dan bertindak secara cepat dan tepat.

Di dalam otak besar (Serebrum) ada terdapat koteks serebri yang terdiri dari 20 area, dimana secara umum area korteks tersebut dibagi menjadi 4 bagian, salah satu bagiannya disebut korteks asosiasi, bagian ini dalam otak yang mengurus kemampuan otak manusia dalam bidang intelektual, ingatan, berpikir, rangsangan yang diterima diolah dan disimpan serta dihubungkan dengan data lain. ${ }^{3}$

Selanjutnya Abdul Rahman dan Muhbib menambahkan bahwa pusat daya pikir manusia terletak pada korteks asosiasi, dimana korteks ini memiliki 3 tonjolan:

1. Tonjolan Panetal, menerima informasi dari indera perasa dan penglihatan yentang bentuk ruang, juga menjadi pengamat untuk kejadian-kejadian khusus

2. Tonjolan Temporal, sebagai pusat pendengaran dan sebagai tempat penympananmemori yang permanen

3. Tonjolan Depan, mengatur kemampuan merencanakan sesuatu dan membayangkan masa depan. 4

Menurut teori lateralisasi (teori tentang organ otak), bahwa bagian terpenting dalam susunan fisiologi otak adalah cerebral cortex, yang tcrbagi dalam dua bulatan: kiri dan kanan. Dua bulatan inilah yang menyebabkan tingkat intelegensi manusia saling berbeda. Hampir 95\% daari klasifikasi jenis pekerjaan manusia berdasar atas dua belahan cerebral cortex. Belahan kiri memberi fungsi respons kemampuan verbal seperti kemampuan menghafal, mengingat, dan memahami sedangkan belahan kanan berfüngsi meberi kemampuan visual spatial. 5

\footnotetext{
${ }^{3}$ Abdul Rahman Shaleh dan Muhbib Abdul Wahab, op. cit., h. 67. Ibid., h. 76.

${ }^{4}$ Ibid., h. 76.

${ }^{5}$ Maria Etty, Perempuan Memutus Mata Rantai Asimetri (Jakarta: PT. Grasindo,
} 2004), h. 68. 
Dari uraian di atas dapat dipahami bahwa dalam struktur otak manusia memiliki bagian dan fungsi terhadap memori. Otak dapat menerjemahkan pesan-pesan yang direkam oleh indera diluar otak, pesan tersebut dapat disimpan dan kemudian bisa dikeluarkan bila suatu saat dibutuhkan.

\section{Kemampuan Memori}

Dalam Kamus Besar Bahasa Indonesia memori, berarti: 1) kesadaran akan mengalaman masa lampau yang hidup kembali: ingatan; 2) catatan yang berisi penjelasan; 3) peringatan, keterangan; 4) piranti komputer yang dapat menyimpan dan merekam informasi. ${ }^{6}$

Arti memori menurut Chaplin sebagaimana yang dikutip oleh Desmita adalah 'keseluruhan pengalaman masa lampau yang dapat .diingat kembali". ${ }^{7}$ Sementara itu Irwanto dkk. Memberikan rumusan tentang memori "sebagai kemampuan untuk menyimpan informasi sehingga dapat digunakan lagi dimasa yang akan datang". ${ }^{8}$

Dari pengertian menurut kamus dan definisi yang dikemukakan oleh para ahli tentang memori, jelaslah bahwa memori adalah suatu kemampuan atau kesadaran dalam menyimpan kejadian-kejadian atau pengalaman masa lampau sehingga dapat diingat kembali.

Selanjutnya memori bisa terjadi karena melaui proses atau tahapan sebagai berikut :

\section{Mencamkan}

2. Menyimpan

3. Memproduksi. $^{9}$

Lebih lanjut Dzakir menjelaskan:

Mencamkan: adalah melekatkan kesan sedemikian hingga tersimpan dan dapat direproduksi. Mencamkan dapat terlaksana secara tidak sengaja apabila kesan yang didapat tidak dengan

${ }^{6}$ Pusat Bahasa Departemen Pendidikan Nasional, Kamus Besar Bahasa Indonesia (Jakarta: Balai Pustaka, 2002), h. 730

${ }^{7}$ Desmita, Psikologi Perkembangan (Bandung: PT Remaja Rosdakarya, 2005), h. 111.

${ }^{8}$ Irwanto dkk Psikologi Umum Buku Panduan Mahasiswa (Jakarta: PT. Gramedia Pustaka Utama, 1991), h. 142

${ }^{9}$ Dzakir, Dasar-Dasar Psikologi (Yogyakarta: Pustaka Pelajar, 1993), h. 55. 
disertai perhatian. Sedang mencamkan dengan sengaja dilaksanakan dengan penuh perhatian, aktif, dan bertujuan.

Menyiman: kesan-kesan yang disimpan dapat bersifat :

a. setia: tersimpan dengan baikdan tidak berubah

b. tahan lama: tersimpau lama

c. luas: banyak kesan yang disimpan

d. patuh: kesan yang telah dicamkan mudah direproduksi

Memproduksi: adalah suatu keaktifan jiwa untuk membangun kembali kesan-kesan yang telah diterimanya. Dalam memproduksi sesuatu yang telah didapat, Dzakir mengutip pendapat Woodworth yang mengistilahkan sebagai berikut:

1. Recall : mengenal kembali untuk diingat.

2. Recognize : mengenal kembali dihadapan bendanya

3. Relerned : ingat kembali karena mempelajari

Ada beberapa jenis ingatan, seperti ingatan sensori mengacu pada informasi asli yang bertahan di organ-organ indera selama beberapa saat, biasanya hanya sepersekian detik, setelah diterima. Ingatan jangka pendek mengacu pada suatu kapasitas ingatan yang terbatas dimana informasi bisa sedikit lebih panjang, biasanya antara 20 sampai 30 detik. Ingatan jangka panjang mengacu pada masuknya informasi yang dapat disimpan untuk jangka waktu yang jauh lebih panjang. ${ }^{10}$

Dalam hal usaha memudahkan ingatan terhadap sesuatu David Matsumoto mengemukakan dua hal, yakni dengan cara (1) Pengulang-ulangan (rehearsal) adalah cara mudah untuk menyimpan informasi dalam ingatan jangka pendek; (2) Pembongkahan (chunking) yakni mengelompokkan butir-butir informasi kedalam bagian-bagian kecil yang bermakna hal ini bisa membantu penyimpanan dan penggunaan kembali informasi.

Sementara menurut Sarlito, untuk mengingat kembali hal-hal yang sudah pernah diketahui ada beberapa cara, yakni sebagai berikut:

1. Rekoleksi, yaitu menimbulkan kembali dalam ingatan suatu peristiwa lengkap dengan segala detail dan hal-hal yang terjadi disekitar peristiwa itu dahulu terjadi. Misalnya

${ }^{10}$ David Matsumoto, Pengantar Psikologi Lintas Budaya, diterj. Anindito Aditomo (Yogyakarta: Pustaka Pelajar, 2004), h. 86. 
seorang pria meningat peristiwa dimana untuk pertama kali ia pergi dengan seorang gadis.

2. Pembaruan ingatan, hampir sama dengan rekoleksi tapi ingatan hanya timbul kalau ada hal yang merangsang ingatan itu. Misalnya dalam contoh di atas ingatan timbul setelah pria tersebut secara kebetulan berjuma kembali dengan gadis yang bersangkutan

3. Memangil Kembali Ingatan, yaitu mengingat kembali suatu hal yang sama sekali terlepas dari hal-hal Iain di masa lalu. Misalnya mengingat sajak Yang diingat disini hanya sajaknya saja. Tetapi pada suatu saat apa sajak itu dipelajari untuk pertama kalinya tidak diperhatikan lagi.

4. Rekognisi, yaitu mengingat kembali sesuatu hal setelah menjumpai sebagian dari hal tersebut. Misalnya ingat suatu lagu setelah endengar sebagian dari nada-nada lagu tersebut

5. Mempelajari Kembali, terjadi kalau kita memelajari sesuatu yang dulu pernah kita pelajari. Maka untuk mempelajari hal yang sama kedua kalinya ini, banyak hal-hal yang akan diingat kembali, sehingga tempo belajar dapat menjadi jaih lebih singkat. ${ }^{11}$

Selanjutnya untuk menjadi bahan renungan perlu ditambahkan sebab-sebab seseorang bisa lupa, sebab hal ini ada kaitan erat dengan ingatan. Dalam literatur ilmiah yang membahas terjadinya sebab-sebab lupa, dapat ditemukan berbagai pandangan antara Iain sebagai berikut:

a. Menurut pandangan Woodworth yang dikutip oleh W.S. Winkel, bahwa gejala lupa disebabkan bekas-bekas ingatan yang tidak digunakan, lamakelamaan terhapus; dengan berlangsungnya waktu, terjadi penghapusan yang suatu bekas ingatan menjadi lamakelamaan hilang sendiri

b. Pandangan yang banyak dukungan dari hasil penelitian pandangan yang mencari terjadinya lupa dalam yaitu gangguan dari informasi baru masuk kedalam ingatan informasi yang telah tersimpan seolah-olah informasi yang digeser dan kemudian lebih diingat

${ }^{11}$ Sarlito Wirawan Sarwono, Pengantar Umum Psikologi (Jakarta: Bulang Bintang, 1976), h. 49. 
c. Pandangan yang Iain menunjuk suatu motif terientu, sehingga sedikit banyak mau sesuatu, misalnya kejadian peristiwa yang tidak lebih muda terlupakan dari pada yang menyenangkan. ${ }^{12}$

Dalam hal lupa, Dzakir pula beberapa penyebabnya, yang antara lain sebagai berikut :

a. karena sakit keras sehingga otak kita terganggu

b. karena kesan yang diterima berlangsung dalam waktu yang lama

c. karena kesan yang diterima menarik perhatian lagi, ingatan tidak menjadi setia

d. karena masuknya tanggapan yang baru, sehingga taggapan yang lama menjadi terdesak

e. karena situasi tertentu. ${ }^{13}$

Berbagai pandangan tentang di atas telah memberikan informasi yang bermakna, mualai dari proses memori yakni dari awal tahapan menyimpan dan memproduksi, sangatlah berarti untuk meningkatkan kualitas ingatan baik dalam belajar, tugas dan aktifitas seharihari. Begitu pula dengan proses menggali ingatan agar hal-hal sudah kita ketahui dapat dengan mudah diingat kembali, berbagai metode menggali ingatan yang telah dipaparkan oleh para ahli tentu bisa dijadikan solusi dalam mengingat segala bentuk pengetahuan atau hafalan yang telah kita miliki, khususnya bagi para khotib. Dimana para khotib lebih banyak bersentuhan dengan materi-materi yang berhubungan dengan hafalan ayat-ayat Al-Qur'an maupun hadis

Tetapi perlu diingat bahwa memori berkaitan langsung dengan lateralisasi atau organ Otak, sehingga boleh jadi kita akan memanfaatkan memori semaksimal mungkin dalam menghimpun berbagai pengetahuan dalam Otak kita. Otak akan menyimpan dengan baik memori tersebut pada saat Otak kita tidak mengalami gangguan, dan akan menolak segala bentuk memori ketika Otak kita dalam keadaan terganggu, sebagaimana telah diulas diatas bahwa ingatan akan terganggu oleh beberapa faktor diantaranya bila Otak terganggu, kesan yang diterima telah berlangsung lama, atau kesan itu tidak menarik perhatian dan juga karena banyaknya informasi yang diterima

\footnotetext{
${ }^{12}$ W.S. Winkel S.J, Psikologi Pengajaran (Jakarta: PT. Gramedia, 1999), h. 509-510

${ }^{13}$ Dzakir, op. cit. h. 59-60
} 
Agar ingatan tetap segar dan mudah digali tentu faktor-faktor diatas harus dijaga dan menjadi perhatian dalam mengembangkan ingatan, sebab bila salah satu faktor ini diabaikan akan menimbulkan kesulitan dalam memanggil kemabali imemori yang telah tersimpan dalam Otak

\section{Metode Penelitian}

Penelitian ini dilakukan di 6 mesjid yang dapat dijangkau oleh penulis di Daerah Bantul dan Sleman, dari 6 mesjid tersebut, ada 7 khotib yang menjadi responsden. Waktu penelitian antara 22 juli sampai dengan 29 juli 2005 dengan menggunakan momen hari jumat. Pengamatan dilakukan secara langsung dan juga dibantu oleh partisipan.

Metode Pengumpulan Data. Dalam penelitian ini penulis menggunakan metode pengamatan langsung terhadap objek penelitian yaitu khatib pada hari jum'at dan wawancara singkat dengan responden atau jama'ah.

Tahap Pelaksanaan Penelitian. Dalam penelitian ini penulis menggunakan tahapan penelitian sebagai berikut:

- Pertama, pada tahap ini penulis mengadakan kegiatan berupa:

1. mendatangi pengurus mesjid

2. mengamati jadwal khotib

3. mengidentifikasi tema materi khotbah (kalau ada)

4. menghadiri jumatan

- Kedua, pada tahap ini saat jumiatan penuliS dan partisipan melakukan :

1. mencatat tema materi khotbah

2. mengamati kesesuaian materi dengan tema khotbah

3. mengamati penguasaan materi dan kefasihan membacakan ayat AI-qur,an atau hadis

4. mengamati ketepatan Uraian materi dengan rukun khotbah jum'at

5. mengamati kesesuaian kesimpulan dengan tema khotbah

6. mengamati penguasaan khotbah kedua

Agar dalam pengamatan penulis lebih terarah dan sistematis maka digunakan tabel / format pengamatan yang memuat komponenkomponen atau aspek-aspek sebagai standar penilaian terhadap kemampuan daya ingat khotib saat menyampaikan materi khotbahnya. Dengan tabel ini akan digunakan menganalisa kemampuan daya ingat khotib. 
Adapun tabel/format pengamatan itu sebagai berikut:

Format/tabel pengamatan

Nama Mesjid

Nama Khotib

Judul Khotbah

Hari / tanggal

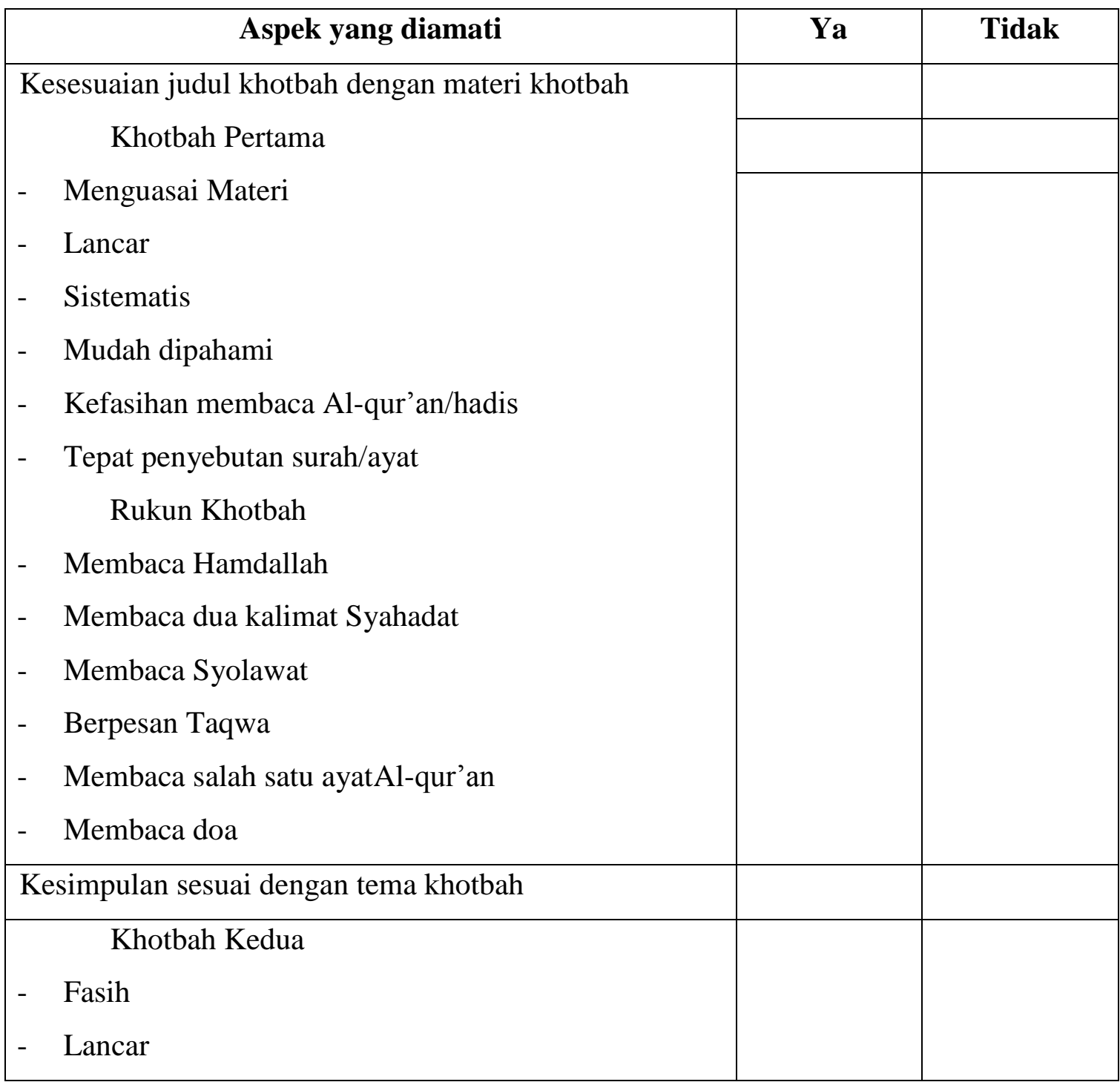


- Ketiga, pada tahap ini, setelah mendengar khotbah penulis sebelum melakukan analisa terhadap hasil pengamatan yang didapatkan dari setiap khotib tentang daya ingat mereka, maka penulis sejenak mengadakan wawancara singkat dengan khotib sekitar persiapan, latar belakang pendidikan, pengalaman berkhotbah serta kegiatan tabligh lain yang digelutinya selain khotbah.

\section{Hasil Penelitian dan Pembahasan}

\section{Karakteristik Responden}

Dalam penelitian yang dilakukan di 6 mesjid dengan 7 khotib, para responden (khotib) adalah mereka yang rata-rata berlatar belakang pendidikan yang cukup tinggi, ada 2 orang berpendidikan S2, berpendidikan SI ada 2 orang, sarjana muda I orang, mahasiswa I orang dan berpendidikan SMU 1 orang.

\begin{tabular}{|l|c|c|c|c|c|}
\hline \multirow{2}{*}{ Nama Responden } & \multicolumn{3}{c|}{ Latar Belakang Pendidikan } & \multirow{2}{*}{ Ket } \\
\cline { 2 - 6 } & SD & SMP & SMU & PT & \\
\hline Drs. Yusuf H. M. Ag & & & & X & S2 \\
\hline Anton S.Pd & & & & X & S1 \\
\hline H. S. Ali Basyir B.A & & & & $X$ & Sarjana Muda \\
\hline Abdul Hamid M.Ag & & & & $X$ & S2 \\
\hline Nuruddin S.Pd & & & & $X$ & S1 \\
\hline H. Rustam & & & $X$ & & SMU \\
\hline Gita Danu P & & & & $X$ & Mahasiswa \\
\hline
\end{tabular}

Melihat status pendidikan yang disandang oleh para khotib, maka mungkin ada benarnya apa yang dikemukakan oleh David Matsumito mengutip pendapatnya Scribner bahwa "kemampuan seseorang dalam mengingat informasi yang tidak saling berhubungan tampaknya tidak begitu dipengaruhi oleh budaya melainkan lebih terkait dengan apakah orang tersebut pct-nah mengeyam sekolah atau tidak". ${ }^{14}$

${ }^{14}$ David Matsumoto, op. cit. h. $88-89$ 
Sementara itu untuk pengalaman berkhotbah dari masing-masing responden dalam berkhotbah menunjukkan bahwa mercka memiliki jadwal dan pengalaman yang cukup tinggi dalam menlaksanakan tugas sebagai khotib sehingga mereka telah terbiasa dan terasah dalam profesi sebagai khotib, atau dengan istilah lain dapat dikatakan bahwa berbicara dihadapan umum mereka sudah tak canggung lagi.

Kemampuan mereka yang berkhotbah juga mungkin karena ditopang oleh kegiatan tabligh selain berkhotbah, katakanlah itu adalah Penguasaan Materi, Lancar, Sistematis, berdakwah, ssehingga diantara mereka ketika berkhotbah tidak Iagi menggunakan naskah, melainkan materi khotbah yang disampaikan itu sudah tersimpan dalam memorinya. Sementara, satu diantara mereka yang masih menggunakan buku saku yang berisi ringkasan khotbah.

Dari pengamatan yang dilakukan terhadap para khotib tergambar sebagai berikut:

\section{Kemampuan Menyesuaikan Judul dengan Materi Khotbah}

\begin{tabular}{|c|l|c|c|c|}
\hline \multirow{2}{*}{ No. } & \multirow{2}{*}{ Nama } & \multicolumn{2}{|c|}{$\begin{array}{c}\text { Kesesuaian judul dengan materi } \\
\text { khotbah }\end{array}$} & \multirow{2}{*}{ Ket } \\
\cline { 3 - 4 } & & Ya & Tidak & \\
\hline 1. & Drs. Yusuf H. M.Ag & $\mathrm{X}$ & & \\
\hline 2. & Anton S.Pd & $\mathrm{X}$ & & \\
\hline 3. & H. S. Ali Basyir B.A & $\mathrm{X}$ & & \\
\hline 4. & Abdul Hamid M.Ag & $\mathrm{X}$ & & \\
\hline 5. & Nuruddin S.Pd & $\mathrm{X}$ & & \\
\hline 6. & H. Rustam & $\mathrm{X}$ & & \\
\hline 7. & Gita Danu P & $\mathrm{X}$ & & \\
\hline
\end{tabular}

Dari tabel diatas dapat diamati bahwa para khotib menyampaikan materi khotbahnya sesuai dengan tema khotbah yang ada, ini artinya bahwa materi itu tidak mcnyimpang dari tema / judul khotbah yang disampaikan pada awal khotbah dan ini pula berarti bahwa khotib dengan kemampuan memorinya mampu mereproduksi kumpulan-kumpulan materi yang tersimpan dan dirangkai dalam satu materi khotbah. 
Penguasaan Materi, Lancar, Sistematis, Mudah dipahami, Kefasihan, dan Ketepatan dalam Penyebutan Surat/ayat

Dari hasilpengamatan yang dilakukan ditemukan beberapa fakta bahwa:

a. Penguasaan materi, 5 dari 7 responden atau $71 \%$ yang benar-bcnar monguasai materi khotbah dan hanya 2 respomden atau $28,57 \%$ yang belum menguasai materi

b. Kelancaran dalam menyampaikan materi yakni 6 dari 7 responden atau $85 \%$ yang brnarbenar lancar dalam menyampaikan materi dan hanya 1 responden atau 14, 29\% yang tidak lancar.

c. Sistematika materi, 5 dari 7 responden atau $71 \%$ mampu menyajikan materi dengan cara yang sistematis, sedangkan 2 responden atau 28,57\% belum sistematis

d. Penyajian yang mudah dipahami, dari 5 dari 7 responden atau $71 \%$ penyajian materinya mudah dipahami, sementara 2 fesponden atau 28,57\% penyajian materinya masih sulit dipahami.

e. Kefasihan dalam membaca ayat Al-Qur'an / hadis,ke 7 responden atau 100\% memiliki kemampuan membaca yang fasih.

f. Penyebutan surah / ayat tcrnyata dari 7 responden atau $100 \%$ menyebut ayat atau hadis tidak keliru

Dari data yang diperoleh juga dapat dipahami bahwa para khotib dengan menguaai materi, lancar dalam menyampaikan, sistematis, mudah dipahami dan fasih serta tepat dalam penyebutan surah maupun ayat, ini menunjukkan betapa para responden memiliki kemapuan memori yang cukup baik sebab, dapat menyusun khotbah secara spontanitas tanpa persediaan naskah yang utuh, hanya katakata kunci dalam bentuk catatan kecil itu pun sekedar formalitas, bahkan dia lancar, fasih, tersimpan dan dirangkai dalam khotbah. sistematis dan tidak keliru dalam penyebutan surah dan ayat pada saat penyampaian khotbahnya. Sementara ada 2 responden dalam hal penguasaan materi masih kurang, 1 responden yang kurang lancar. 2 responden yang kurang sistematis dan ada 2 responden yang kurang dipahami ulasan materinya.

Menurut analisa penulis, adanya responden yang belum maksimal dalam penyampaian khotbah, boleh jadi karena jam terbang mereka dalam berkhotbah masih kurang atau hafalan dan memori mcreka tentang pengetahuan agama maupun pengetahuan umum terbatas sehingga materi yang mereka ketahui pun masih pas-pasan akibatnya, mereka mengalami kesulitan dalam mereproduksi ingatan mereka saat berkhotbah. 


\section{Kemampuan Mentori Terhadap Rukun Khotbah}

Data hasil pengamatan menunjukkan bahwa $100 \%$ responden meiliki kcmampuan memori yang sama terhadap rukun khotbah, mulai dari menucapkan Hamdallah, membaca dua kalimat syahadat, membaca syolawat, berpesan taqwa dan membaca salah satu ayat AlQur'an dan membaca doa

Menurut analisis pcnulis, adanya kemampuan memori khotib terhadap rukun khotbah, hal itu disebabkan Oleh adanya suatu motivasi yang kuat yang sudah tertanam pada setiap diri khotib, bahwa bila dalam khotbah jumat, salah satu rukun khotbahnya terlupakan maka khotbah itu dianggap kurang sempurna.

Hal tersebut senada dengan apa yang dikemukakan oleh W.S Winkel bahwa "suatu memori akan tersimpan lama, setia pada Otak manusia bila ada motivasi yang kuat terhadap memori tersebut". ${ }^{15}$

Motivasi merupakan dorongan dalam diri yang dapat menjadi pemicu/penggerak dalam melakukan sesuatu termasuk dalam hal ini adalah aktivitas mengingat.

\section{Kesimpulan Sesuai Dengan Tema Khotbah}

\begin{tabular}{|c|l|c|c|c|}
\hline \multirow{2}{*}{ No. } & \multirow{2}{*}{ Nama } & \multicolumn{2}{|c|}{ Kesimpulan sesuai dengan tema } & \multirow{2}{*}{ Ket } \\
\cline { 3 - 4 } & & Ya & Tidak & \\
\cline { 3 - 4 } 1. & Drs. Yusuf H. M.Ag & $\mathrm{X}$ & & \\
\hline 2. & Anton S.Pd & $\mathrm{X}$ & & \\
\hline 3. & H. S. Ali Basyir B.A & $\mathrm{X}$ & & \\
\hline 4. & Abdul Hamid M.Ag & $\mathrm{X}$ & & \\
\hline 5. & Nuruddin S.Pd & $\mathrm{X}$ & & \\
\hline 6. & H. Rustam & $\mathrm{X}$ & & \\
\hline 7. & Gita Danu P & & $\mathrm{X}$ & \\
\hline
\end{tabular}

Ada 6 dari 7 responden atau 85\% yang benar-benar mampu memberikan kesimpulan khotbahnya sesuai dengan judul khotbah yang disampaikan sebelumnya, scmentara hanya I responden atau 14,29\% yang kurang mampu menyimpulkan materi khotbahnya.

${ }^{15}$ W.S. Winkel op. cit., h. h. 561 
Menurut analisis penulis, khotib yang kurang mampu menyusun suatu ulasan sebagai kesimpulan dari satu materi ceramah atau khotbah, dapat disebabkan kemungkinan oleh keamampuan dasar dari keccrdasan linguistiknya belum terasah dengan baik, karena dengan "kecerdasan linguistik seseorang dapat menjelaskan, mcngaj arkan, menceritrakan pemikirannya kepada orang lain, bahkan menghafalkan ceritra yang panjang dengan perbendaharaan kata yang bervariasi, lancar dan mudah. ${ }^{16}$ Dan, kcmungkinan lupa, karena kondisi mental terutama khotib pemula yang masih gugup berhadapan dengan jama'ah yang banyak. Oleh Dzakir hal ini diistilahkan dengan pengaruh kondisi tertentu. ${ }^{17}$

\section{Penguasaan Khotbah Kedua}

\begin{tabular}{|c|l|c|c|c|c|}
\hline \multirow{2}{*}{ No } & \multirow{2}{*}{ Nama } & \multicolumn{4}{|c|}{ Penguasaan khotbah kedua } \\
\cline { 3 - 6 } & & \multicolumn{2}{|c|}{ Fasih } & \multicolumn{2}{c|}{ Lancar } \\
\cline { 3 - 6 } & & Ya & Tidak & Ya & Tidak \\
\hline 1. & Drs. Yusuf H. M.Ag & $\mathrm{X}$ & & $\mathrm{X}$ & \\
\hline 2. & Anton S.Pd & $\mathrm{X}$ & & $\mathrm{X}$ & \\
\hline 3. & H. S. Ali Basyir B.A & $\mathrm{X}$ & & $\mathrm{X}$ & \\
\hline 4. & Abdul Hamid M.Ag & $\mathrm{X}$ & & $\mathrm{X}$ & \\
\hline 5. & Nuruddin S.Pd & $\mathrm{X}$ & & $\mathrm{X}$ & \\
\hline 6. & H. Rustam & $\mathrm{X}$ & & $\mathrm{X}$ & \\
\hline 7. & Gita Danu P & & $\mathrm{X}$ & & $\mathrm{X}$ \\
\hline
\end{tabular}

Dari tabel di atas dapat diketahui bahwa:

a. 6 dari 7 responden atau $85 \%$ fasih dalam melafadzkan doa dalam khotbah kedua, dan hanya 1 responden atau yang kurang fasih

b. 6 dari 7 responden atau $85 \%$ lancar dalam melafadzkan doa dalam khotbah kedua, dan hanya 1 responden atau 14,29 yang kurang lancar.

${ }^{16}$ Paul Supamo, Teori Intelegensi Ganda dan Aplikasinya di Sekolah Cara Menerapkan Teori Multiple Intelegences Howard Gardner (Yogyakarta: Kanisius, 2004), h. 26-27.

${ }^{17}$ Dzakir, op. cit., h. 60. 
Kefasihan dan kelancaran 6 dari 7 responden dalam melafadzkan doa, hal ini sangatlah dimungkinkan karena doa-doa terscbut sudah biasa dipakai dalam doa setiap shalat lima waktu atau aktifitas hajatan lainnya, sehingga para responden tidak mengalami kesulitan dalam mengingat kembali. Sebagaimana terori Matsumoto, bahwa" Pengulang-ulangan (rehearsal) adalah salah satu cara yang mudah untuk menyimpan informasi dalam ingatan jangka pendek dan kemudian ingetan jangka panjang. ${ }^{18}$ Bagi responden yang tidak fasih dan lancar mungkin doa ini belum terbiasa dipakai, sehmgga belum tersimpan dalam memori akibatnya mengalami kesulitan dalam melafadzkannya.

\section{Penutup}

Tugas intelektual lain yang dialami semua orang dalam menghadapi dunia adalah mengingat berbagai hal. Kita mengalami susahnya berusaha menghafal untuk ujian dan mengalami keSuitan saat berusaha mengingatingat daftar tanggal ataw nama atau berbagai informasi dan aktaivitas lainnya, bila memungkinkan kita akan mengunakan alat bantu seperti daftar belanjaan, kalender, ringkasan catatan kecil yang memuat kata- kata kunci, untuk membantu kita mengingat hal-hal yang kita tahu berdasarkan pengalaman yang biasanya kita lupakan.

Seorang khotib pun dalam menyampaikan khotbah tentu tidak lepas dari kesusahan menghafal dan kesulitan dalam mengingat-ingat materi khotbah, akan tetapi sebagaimana dalam penelitian ini ada beberapa hal disimpulkan yang dapat mendukung ingatan para khotib:

a. Latar belakang pendidkan, dimana ratarata responden pernah mengeyam bangku pendidikan SMU bahkan sampai perguruan tinggi. Ini berarti bahwa responden yang pernah sekolah lebih banyak berlatih menghafal dibandingkan dengan yang tidak sckolah. Individu yang mengenyam sekolah juga marnpu menerapkan ketrampilan ingatan tersebut dalam situasi dan kegiatan lain.

b. Aktivitas dan profesi sebagai tenaga pendidik, ataupun mubaligh dari para responden adalah wadah yang dapat menambah dan memperluas informasi tentang materi agama, sehingga dengan mudah informasi terebut direproduksi kembali pada saat melaksanakan khotbah.

${ }^{18}$ David Matsumoto, op. cit., h. 86. 
c. Penggunaan alat bantu berupa catatan kecil yang berisi kata-kata kunci adalah upaya kreatif para khotib dalam meningkatkan kemampuan memori. Hal ini senada dengan apa yang ditulis Dr. Sugiayanto dalam makalahnya bahwa dalam peningkatan kemampuan memori ada beberapa upaya yang dapat dilakukan, salah satunya dengan alat bantu. ${ }^{19}$

${ }^{19}$ Sugiyanto, Makalah Psikologi Kognitif Magister Studi Islam ULMY, Yogyakarta, 2004, h. 21. 


\section{Daftar Pustaka}

Abdul Rahman Shaleh dan Muhbib Abdul Wahab. 2004. Psikilogi Suatu Pengantar Dalam Perspektif Islam. Jakarta: Pernada Media

Desmita. 2005. Psikologi Perkembangan. Bandung: PT Remaja Rosdakarya.

Dzakir. 1993. Dasar-Dasar Psikologi. Yogyakarta: Pustaka Pelajar.

Irwanto, dkk 1991. Psikologi Umum Buku Panduan Mahasiswa. Jakarta: PT Gramedia Pustaka Utama

Maria Etty. 2004. Perempuan Memutus Mata Rantai Asimetri. Jakarta: PT Grasindo.

Matsumoto, David. 2004. Pengantar Psikologi Lintas Budaya. Diterj. Anindito Aditomo. Yogyakarta: Pustaka Pelajar.

Paul Supamo. 2004. Teori Intelegensi Ganda dan Aplikasinya di Seko/ah Cara MenerapkanTeori Multiple Intelegences Howard Gardner. Yogyakarta: Kanisius.

Pustaka Suara Muhammadiyah, Tuntunan Tabligh Jilid I, Mitra Grafika, Yogyakarta, 1997

Pusat Bahasa Departemen Pendidikan Nasional, Kamus Besar Bahasa Indonesia, Balai Pustaka, Jakarta, 2002

Sarlito Wirawan Sarwono, Pengantar Umum Psikologi, Bulang Bintang, Jakarta, 1976

Sugiyanto.2004. "Psikologi KognitiT", Makalah Magister Studi Islam UM Y Yogyakarta.

Winkel, W.S. 1999. Psikologi Pengajaran. Jakarta: P T. Gramedia. 